\title{
Bilgisayar Destekli FPGA Tabanlı Sayısal Sistemler Deney Seti Tasarımı Araştırma Makalesi/Research Article
}

\author{
Mevlüt ERSOY, (iD Cem Deniz KUMRAL \\ ${ }^{1}$ Bilgisayar Mühendisliği, Süleyman Demirel Üniversitesi, Isparta, Türkiye \\ mevlutersoy@sdu.edu.tr, cemkumral@ isparta.edu.tr \\ (Geliş/Received:28.06.2020; Kabul/Accepted:02.07.2021) \\ DOI: $10.17671 /$ gazibtd. 759242
}

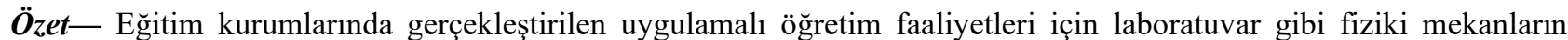
oluşturulması gerekmektedir. Bu tür öğretim faaliyetlerine katılan öğrencilerin konuyu daha iyi anlamaları için konu ile ilgili deney ortamlarının oluşturulması konuların anlaşılma seviyesini arttırmaktadır. Bu deney ortamları oluşturulurken uygulama konusuyla ilgili deney setlerinin mevcut olması eğitimin kalitesini artırmada etkili olmaktadır. Günümüzde kullanılan deney setleri gerek içerik olarak yetersiz kalmakta gerekse eğitim kurumlarına maliyetli olmaktadır. Bu çalışmada, Sayısal İletişim, Sayısal Elektronik ve Mantıksal Tasarım derslerinin eğitimini veren lise ve üniversite düzeyindeki kurumlarda söz konusu derslerin uygulamalarını tek bir deney seti üzerinde daha etkin ve daha anlaşılabilir bir düzeyde gerçekleştirmek amaçlanmıştır. Geliştirilen deney setinin mantıksal işlemleri FPGA platformu üzerinde gerçekleşmektedir. FPGA'lar sayısal iletişim, mantıksal devreler, kombinasyonel devrelerin tasarımları ve kontrol devreleri gibi birçok alanda kullanılabilmektedir. Oluşturulan tasarım ile farklı dersler ve konuları içeren uygulamaların, deney elemanlarının veya tümleşik devre tasarımlarının FPGA üzerinde VHDL aracılığıyla tasarımları yapılarak tek bir deney seti üzerinde toplanması sağlanmıştır. Gerçekleştirilen çalışma sonucunda, eğitim kurumlarının laboratuvar malzemeleri için ayırmış oldukları mali kaynakları azaltacak ergonomik, taşınabilir, kullanııı dostu ve eğitmenin öğrenciyi ağ ortamından uzaktan takip edebileceği tümleşik bir deney seti tasarımı oluşturulmuştur.
\end{abstract}

Anahtar Kelimeler — deney seti tasarımı, fpga, vhdl, sayısal sistemler

\section{Computer Supported FPGA Based Digital Systems Experiment Set Design}

\begin{abstract}
Physical places such as laboratories should be created for applied teaching activities in educational institutions. In order for the students participating in such teaching activities to understand the subject better, creating experimental environments related to the subject increases the level of understanding of the topics. The existence of experiment sets related to the subject of application while creating these experimental environments is effective in increasing the quality of education. The experiment sets used today are both insufficient in content and costly to educational institutions. In this study, it is aimed to carry out the applications of these courses in a more effective and more understandable level on a single set of experiments in high school and university level institutions that teach Digital Communication, Digital Electronics and Logical Design courses. The logical operations of the developed experiment set take place on the FPGA platform. FPGAs can be used in many fields such as digital communication, logical circuits, designs of combinational circuits and control circuits. With the created design, applications containing different courses and subjects, experimental elements or integrated circuit designs were designed on FPGA by VHDL and gathered on a single experiment set. As a result of the work carried out, an integrated experiment set design has been created, which will reduce the financial resources allocated by educational institutions for laboratory materials, ergonomic, portable, user-friendly and the instructor can follow the student remotely from the network environment.
\end{abstract}

Keywords - experiment set design, fpga, vhdl, digital systems 


\section{GIRİŞ (INTRODUCTION)}

Eğitim kurumlarında gerçekleştirilen uygulamalı öğretim faaliyetleri için laboratuvar gibi fiziki mekanların

rulurken uygulama konusuyla ilgili deney setlerinin kullanılması eğitimin kalitesini artırmaktadır. Günümüzde içeriklerinin kısıtlı olması, maliyetlerinin yüksek olması gibi sebeplerden dolayı eğitim kurumlarında deney setlerinin kullanımı kısıtlanmaktadır. Aynı zamanda sınıf mevcutlarının yüksek olması sebebiyle uygulamaların kontrolleri zorlaşmaktadır. $\mathrm{Bu}$ durum uygulamalı eğitimlerde yetersizliklere yol açmakta ve uygulamal eğitimlerin simülasyon ortamlarına geçirilmesine neden olmaktadır [1-3].

Günümüzde farklı amaçlar için geliştirilmiş deney seti tasarımları bulunmaktadır. Bu deney setleri ticari veya akademik ortamlarda geliştirilmektedir [4-6]. Ticari deney setleri genellikle ortaöğretim ve yükseköğretim düzeyinde sayısal elektronik, sayısal iletişim, devre analizleri, hidrolik sistemler gibi derslerin içerdiği konuları kapsayacak şekilde üretilmektedir. Bilgisayar kontrollü deney setleri ile ilgili akademik çalışmalar incelendiğinde farklı konuları içeren deney seti tasarımları yapılmıştır. $\mathrm{Bu}$ tasarımlarda temel elektronik derslerinde kullanılabilen deney seti [7], web üzerinden kontrol edilebilen güç elektroniği dersi için geliştirilmiş deney seti [8], internet üzerinden mikroişlemci deneylerinin yapılmasını sağlayabilen deney seti [9], temel haberleşme deneylerinin yapılabildiği deney seti [10], bilgisayar tabanlı katı maddelerin harmonik hareketlerini sağlayan deney seti [11] gibi çalışmalar yapılmıştır. Köksal [12], analog haberleşme elemanlarının kontrol edilebilmesi için mikrobilgisayar sistemli bir deney seti tasarımı gerçekleştirerek analog sinyalleri kontrol edebilme ve işleyebilme özelliği olan deney seti tasarımı gerçekleştirmiştir. Sarı [13], geliştirildiği deney setinde Otomasyon sistemleri dersinde PLC tabanlı deney seti tasarımı gerçekleştirerek elektronik ve mekanik sistemlerin bir arada kullanılmasını sağlamıştır. Karthik vd. [14] çalışmalarında, FPGA tabanlı sistem tasarımının işlevsel olarak doğrulanması için Raspberry Pi aracılığıyla FPGA pinlerini gözlemleme ve kontrol etme üzerine araştırmalar yapmışlardır. Ișık ve Tağluk [15], İki Seviyeli Faz Kaydırmalı Anahtarlama (BPSK) ve Dört Seviyeli Faz Kaydırmalı Anahtarlama (QPSK) modelleri üzerine Alanda Programlanabilir Kapı Dizileri (FPGA) tabanlı bir gömülü haberleşme sistem tasarımı gerçekleştirmişlerdir. Arıcı [16], deneyler üzerinden veri toplamak için mikrodenetleyici tabanlı bir veri toplama sistemi oluşturarak basit elektronik devrelerde eğitim amaçlı kullanılabileceğini vurgulamıştır. $\mathrm{Bu}$ çalışmalar incelendiğinde genellikle tek bir konuyu içeren çalışmalar yapılmıştır.

$\mathrm{Bu}$ deney setlerinin tasarımlarında her deney için elektronik devre tasarımı yapılırken bazı deney setlerinde gömülü sistem veya Alanda Programlanabilir Kapı Dizileri (FPGA - Field Programmable Gate Array) kullanıldığı görülmüştür. oluşturulması gerekmektedir. Bu tür öğretim faaliyetlerine katılan öğrencilerin konuyu daha iyi anlamaları için konu ile ilgili deney ortamlarının oluşturulması gerekmektedir. $\mathrm{Bu}$ deney ortamları oluştu

Günümüz koşullarında gerek yurt içinde gerekse yurt dişında geliştirilen ve kullanılan deney setlerine bakıldığında ilgili derslere ait uygulamalar her ders veya konu için farklı deney setleri veya ek modüller kullanılarak yapılmaktadır. Örneğin; Veri İletişim dersi için modülasyon sağlayan deney setlerinde genlik modülasyonu ile frekans modülasyonu farklı deney setleri üzerinde uygulanmaktadır. Kodlama teknikleri için oluşturulan deney setlerinde her bir kodlama farklı deney setleri üzerinde gösterilmektedir. Ayrıca bu deney setlerinin çalışma prensipleri genel olarak deney ile ilgili devrelerin fiziksel tasarımları ile gerçekleştirilmektedir. Geliştirilen deney seti tasarımında farklı konuları kapsayan deneylerin tümleşik hale getirilerek tek bir deney seti şeklinde kullanıma sunulması amaçlanmıştır. Ayrıca günümüzde uygulamalı derslerde gerçekleştirilen deneylerin kontrolleri eğitimciler tarafından her öğrenci için tek tek yapılmaktadır. Çalışmadaki deney seti tasarımında belirli verilerin kayıtlarını tutarak eğitimcilerin uzaktan deney kontrolü yapabilmesine katkı sağlamak hedeflenmektedir.

Bu çalışmada, ortaöğretim ve yükseköğretim düzeyindeki kurumlarda Sayısal İletişim ve Sayısal Elektronik derslerinde gerçekleştirilen uygulamaları içeren tümleşik bir deney seti tasarımı geliştirilmiştir. Geliştirilen tümleşik deney setinin arayüz uygulaması ve deney seçimlerinde Raspberry Pi gömülü sistemi kullanılmıștır. Deneylere ait devre elemanları FPGA kartı üzerinde VHDL kullanılarak tasarlanmıştır. Raspberry Pi ile FPGA haberleşmesinde deney devre elemanlarının seçim aşamasında özel bir kodlama sistemi belirlenmiștir. Raspberry $\mathrm{Pi}$ üzerinden seçilen deneylerde ihtiyaç duyulan devre elemanları Grafik LCD panellerde görüntülenerek devre tasarımı için ortam oluşturulmuştur. $\mathrm{Bu}$ ortamda Grafik LCD panellerin kenarlarında yer alan pinler sayesinde deney elemanlarına giriş ve çıkış işlemleri yapılmasına imkân sağlanmıştır. Ayrıca deney seti üzerinde öğrencilerin yapmış oldukları işlemler veritabanına aktarılarak bir deney log (seyir) sistemi oluşturulmuştur.

Gerçekleştirilen çalışma sonucunda, eğitim kurumlarının laboratuvar malzemeleri için ayırmış oldukları mali kaynakları azaltacak bir tasarım oluşturulmuştur. Eğitimlerde gerçekleştirilecek olan deneylerin hazırlık süreçleri kısaltılmış, deneylerin başarımının deney seti üzerinden takip edilebilmesi sağlanmış ve eğitim alan öğrencilerin eğitimden etkin bir biçimde fayda sağlaması imkânı elde edilmiştir. Bu özellikler sayesinde ergonomik, taşınabilir, kullanıcı dostu, eğitmenin öğrenciyi ağ ortamından uzaktan takip edebileceği tümleşik bir deney seti tasarımı oluşturulmuştur. 


\section{MATERYAL VE YÖNTEM (MATERIAL AND METHOD)}

2.1. FPGA Mimarisine ve VHDL Diline Genel Bakış (FPGA Architecture and VHDL Language Overview)

FPGA'lar sayısal tasarım konusunda tasarımciya kolayca sayısal devre tasarlamasına ve yapılan tasarımların prototip bir cihaz üzerinde fiziksel bir ortamda gerçekleştirilip test edilip doğrulanmasına olanak sağlayan entegre devrelerdir. Üzerinde bulunan transistör miktarına göre tasarımc1 herhangi bir entegrenin veya entegrelerin yapabildiğ bütün işlemleri tek bir FPGA üzerinde tasarlayıp gerçekleyebilir. FPGA'ler günümüzde tüketici elektroniğinden, uzay ve savunma sanayisinden, otomotiv sanayisine kadar çok farklı alanlarda kullanılmaktadır. FPGA'lar; programlanabilir mantık blokları, bu blok dizisini çevreleyen giriş-çıkış blokları ve ara bağlantılar olmak üzere düzenlenebilir üç ana bölümden oluşmaktadır. $\mathrm{Bu}$ kartlar üretim aşamasından sonra tasarımcının istediğ fonksiyona göre donanım yapısını değiştirmesine olanak sağlar. FPGA mimarisinde mantık hücrelerine Slice, mantık işlemlerini yerine getiren birimlere de LUT (Look Up Table) adı verilmektedir. Bu birimler FPGA'nın kaynakları olarak adlandırılmaktadır.

FPGA tasarımını oluşturmak için kullanıcı tarafından bir şematik dizayn oluşturulmalıdır. Günümüzde FPGA uygulaması tasarlamak için kullanılan en yaygın donanım tanımlama dili VHDL'dir. Bundan farklı olarak Verilog dili de kullanılmaktadır. Geliştirilen deney setinin FPGA devre tasarımı işlemlerinde VHDL kullanımı tercih edilmiştir.

Günümüzde kullanılan deney setleri uygulamalı bir dersin altyapısını sağlayan devre elemanlarını içermektedir. $\mathrm{Bu}$ deney setleri her ders veya konu için özel olarak geliştirilmiştir. Deney setlerinin tasarımında sabit bir devre yapısı bulunmakta ve bu devrenin amacına göre sabit bir işlem gerçekleştirilmektedir. Geliştirilen deney seti tasarımında deneylerin devre tasarımları FPGA kartı ile oluşturulmuştur. FPGA kartının kontrol amaçlı kullanılmasının ana sebebi; bu platformun çok sayıda devre tasarımını ekstra malzeme ve fiziksel devre tasarımı gerektirmeden kodlama mantığıyla oluşturabilmesidir. $\mathrm{Bu}$ sayede gerek sayısal devreler gerekse sayısal iletişim deneylerinin devre elemanları tek bir deney seti üzerinde toplanabilmektedir. $\mathrm{Bu}$ durumda eğitim kurumları bu dersler için ayrı ayrı deney seti veya deney seti modülü almalarına gerek kalmamakta ve bu sayede eğitim kurumlarının laboratuvar maliyetleri düşürülebilmektedir. Deney setinin kapsamının genişletilmesi ve deney sayısının artması durumunda FPGA kartı yüksek performans, kararlı çalışma ve deneylerdeki giriş-çıkış işlemleri için yeterli miktarda bağlantı noktası sağlayacaktır.

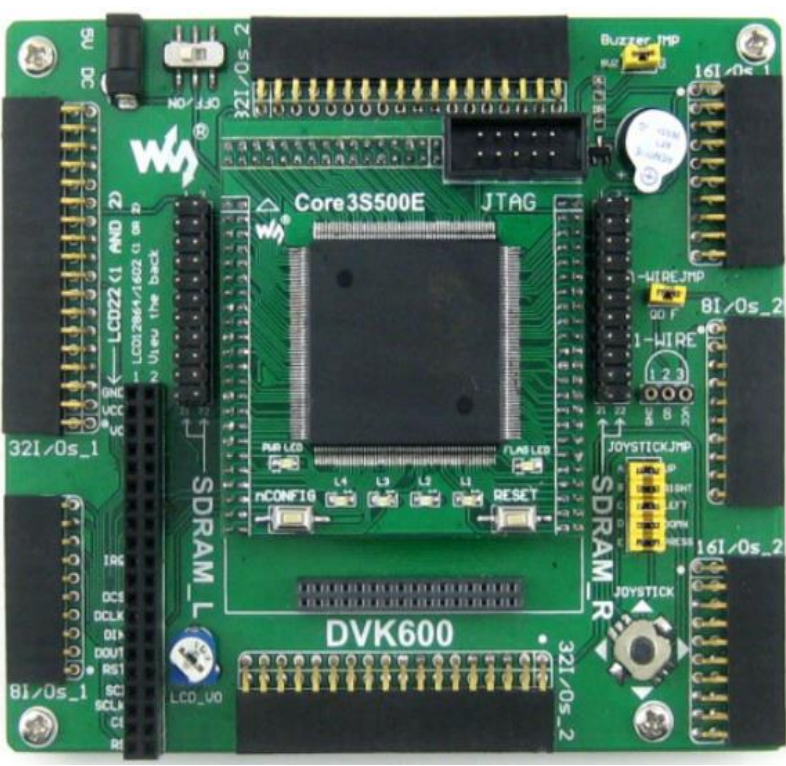

Şekil 1. Xilinx Spartan XC3S500E FPGA kartı (Xilinx Spartan XC3S500E FPGA board) [17]

Tablo 1. Spartan XC3S500E karakteristik özellikleri (Spartan XC3S500E characteristic features) [18]

\begin{tabular}{|l|c|}
\hline Karakteristik Özellik & Kapasitesi \\
\hline Toplam Mantık Kapısı & 10476 \\
\hline Toplam Mantık Hücresi & $500 \mathrm{~K}$ \\
\hline Toplam Mantık Bloğu & 1164 \\
\hline Toplam Slice & 4656 \\
\hline Toplam LUT & 9312 \\
\hline RAM Kapasitesi & $360 \mathrm{~K}$ \\
\hline Giriş-Çıkış Pini & 116 \\
\hline
\end{tabular}

$\mathrm{Bu}$ çalışmada, deney setinin mantıksal işlemlerinin gerçekleştirilmesi Xilinx Spartan XC3S500E FPGA kartı ile sağlanmıştır. Birçok karta göre daha fazla genişlemeyi destekleyen bir FPGA çekirdek kartıdır. Bu genişleme özelliği sayesinde birçok çevre birim ile kolaylıkla haberleşebilmekte ve uygulamalarda yürütülecek iş paketleri daha tümleşik ve daha hızlı bir biçimde gerçekleştirilebilmektedir. Söz edilen FPGA kartının yüksek çalışma performansına sahip olması ve deney setinde kullanılacak çevre birimler için yeterli bir genişleme sağlaması sebebiyle geliştirilen deney setinde kullanılması uygun bulunmuştur. Kullanılan FPGA kartının fiziksel görüntüsü Şekil 1'de, karakteristik özellikleri ise Tablo 1'de verilmiştir.

\subsection{Deney Seti Tasarımı (Design of Experiment Set)}

Şekil 2'ye göre, deney seti tasarımında Raspberry Pi "Gömülü Sistem Bilgisayarı" üzerine bir "Dokunmatik LCD Kontrol Arayüzü” uygulaması geliştirilmiştir. Geliştirilen deney setinin blok diyagramı Şekil 2'de verilmiştir. 
Uygulamayı geliştirebilmek amacıyla Raspberry Pi üzerine bir SD kart aracılığıyla Linux tabanlı Raspbian işletim sistemi kurulmuştur. Uygulamanın yazılım sürecinde açık kaynak kodlu bir programlama dili olan Java kullanılmıştır. Geliştirme ortamı olarak ise açık kaynak olarak kullanılabilen NetBeans platformu tercih edilmiştir. Arayüz uygulaması ile aynı ağda bulunan bir "Veritabanı Sunucusu" oluşturulmuştur. Yürütülen tüm veritabanı işlemleri için açık kaynak kodlu bir veritabanı yönetim sistemi olan MySQL kullanılmıştır. Oluşturulan veritabanında deney bilgileri, öğrencilerin hangi deneyleri tamamladıkları, öğrencilerin deneylerin tasarım süreçlerinde yapmış oldukları işlemlerin logları tutulmuştur. Veritabanında tutulan bu verilerin "Eğitimci Kontrolü” arayüzünde görüntülenmesi sağlanmıştır. Deney setinin mantıksal işlemlerinin gerçekleştirilmesi Xilinx Spartan XC3S500E FPGA kartı ile sağlanmıştır. Kullanılan FPGA kartı Xilinx ISE 14.7 geliştirme ortamını desteklemektedir. Deney setinin mantıksal işlemleri VHDL kullanılarak bu geliştirme ortamında programlanmıştır. Windows 10 işletim sisteminde ISE 14.7 sürümünün desteklenmemesi sebebiyle WMware sanal makinesi üzerine Windows 7 işletim sistemi kurularak FPGA tasarımları bu platformda geliştirilmiştir. FPGA işlemcisinin portlarının daha etkin kullanılabilmesi için bir genişletme kartı kullanılmıştır. Bu genişletme kartı sayesinde FPGA' de tasarlanan mantıksal devrelerin giriş - çıkış işlemlerini ve kullanıcılarla etkileşimlerini sağlamak için “Grafik LCD Kontrol Arayüzü” üzerindeki grafik LCD panele ait portların bağlantıları birleştirilmiştir. $\mathrm{Bu}$ elektronik bağlantıları temsil eden görsel Şekil 3'te verilmiştir. Deney setinde gerçekleştirilecek deneylere giriş verisi sağlayabilmek amacıyla On/Off Anahtar grubu, çıkış değerlerini gözlemleyebilmek amacıyla LED grubu, Motor Sürücü ve 7 Segment Display sürücü eklenmiştir.

Deney setinin eğitimci ve öğrenci işlemlerini temsil eden akış diyagramı Şekil 4'te deney seti için geliştirilen ön yüz tasarımı ise Şekil 5'te verilmiştir.

\subsection{Gömülü Sistem ile FPGA Platformunun Haberleşmesi (Communication of the Embedded System and FPGA platform)}

Gömülü sistem bilgisayarından aktarılan deney verileri FPGA platformu üzerinde tanımlanmış haberleşme pinleri üzerinden alınmaktadır. Kullanıcıların dokunmatik LCD ekran üzerinden seçtiği deneylere göre arayüz uygulamasından gelen deney verisinin FPGA işlemcisinde yürütülen süreçlerden hangisine uygun olduğu kontrol edilmektedir. $\mathrm{Bu}$ altyapı oluşturulurken, haberleşme esnasında veri kaybı ve gecikme durumlarının önüne geçilmeye çalışılmıştır. Oluşturulan tasarımında bu problemlerle karşılaşmamak amacıyla gömülü sistem kartı ile FPGA kartı arasındaki haberleşmenin her iki kart üzerinde de bulunan giriş-çıkış pinleri aracılığıyla gerçekleştirilmesi sağlanmıştır. Haberleşme işlemini gerçekleştirebilmek için deney seti kapsamında uygulanacak deney sayısı ve bu deneylerin içeriklerine göre haberleşme pinlerinin sayısı belirlenmiştir. Haberleşme esnasında her bir deney çeşidi için ayrı bir giriş-çıkış pini kullanmak gömülü sistem ve FPGA kartlarının sunduğu toplam pin sayısını büyük oranda işgal etmektedir. Bu sorunu aşmak adına hem gömülü sistem bilgisayarı hem de FPGA kartı üzerinde belirli sayıda pinler seçilerek İkilik Sayı Sistemi (Binary) üzerinden sağlanan bir haberleşme protokolüne atanmıştır. Geliştirilen deney setinin içeriğinde 16 farklı deney senaryosu bulunmaktadır. 16 adet farklı deney verisini ikilik sayı sistemi formatında iletebilmek için gömülü sistem ve FPGA kartları üzerinde 5'er adet pin haberleşme işlemi için ayrılmıştır. Her bir pin ikilik sayı sisteminde bir biti temsil etmekte ve bu sayede deney verilerini aktarabilmek için iletim tetiklemeleri elde edilmektedir. Geliştirilen deney seti tasarımına eklenen deneylerin gömülü sistem ile FPGA platformu arasındaki haberleşme kodları Tablo 2'de verilmiştir.

Tablo 2. Deneylerin haberleşme kodları (Communication codes of the experiments)

\begin{tabular}{|c|c|}
\hline Deney Adı & Haberleşme Kodu \\
\hline Değil Kapısı & 00000 \\
\hline VE Kapısı & 00001 \\
\hline VEYA Kapısı & 00010 \\
\hline $\begin{array}{c}\text { Kombinasyonel Devre } \\
\text { Tasarımı }\end{array}$ & 00011 \\
\hline Yarım Toplayıcı Devre & 00100 \\
\hline Tam Toplayıcı Devre & 00101 \\
\hline Yarım Çıkarıcı Devre & 00111 \\
\hline Tam Çıkarıcı Devre & 01000 \\
\hline Karşılaştırıcı Devre & 01001 \\
\hline 4x1 MUX & 01010 \\
\hline 7 Bölmeli Gösterge Sürme & 01011 \\
\hline D Flip-Flop & 01100 \\
\hline JK Flip-Flop & 01101 \\
\hline NRZ Kodlama & 01110 \\
\hline Manchester Kodlama & 01111 \\
\hline Differential Manchester & 10000 \\
\hline Kodlama & \\
\hline
\end{tabular}

Haberleşme protokolü geliştirilirken, FPGA'nın kendisine aktarılan verinin hangi deneye ait olduğunu anlayabilmesi amacıyla her bir deney türü için özel iletim numarası belirlenmiştir. Örneğin; "VEYA Kapısı” deneyinin iletim numarası "2" olarak atanmıştır. Kullanıcı dokunmatik ekrandan bu deneyi seçtiği takdirde, gömülü sistem bilgisayarından FPGA kartına deney türü verisini iletecek 5 adet haberleşme pini “ 00010 ” şeklinde bir tetikleme gerçekleştirmektedir. Her deney türü için atanmış olan iletim numarası eşsiz olduğu için platformlar arasındaki haberleşme kararlı ve hızlı bir biçimde sağlanmıştır. Bu kontrol sonucunda eşleşen deneyin giriş ve çıkış pinleri FPGA üzerinde aktif edilerek grafik LCD panellerin yanında bulunan portlarda kullanılmaya hazır hale getirilmektedir. FPGA üzerinde geliştirilen tasarımın Xilinx ISE 14.7 ortamındaki örnek VHDL kod parçası şekil 6'da verilmiştir. 


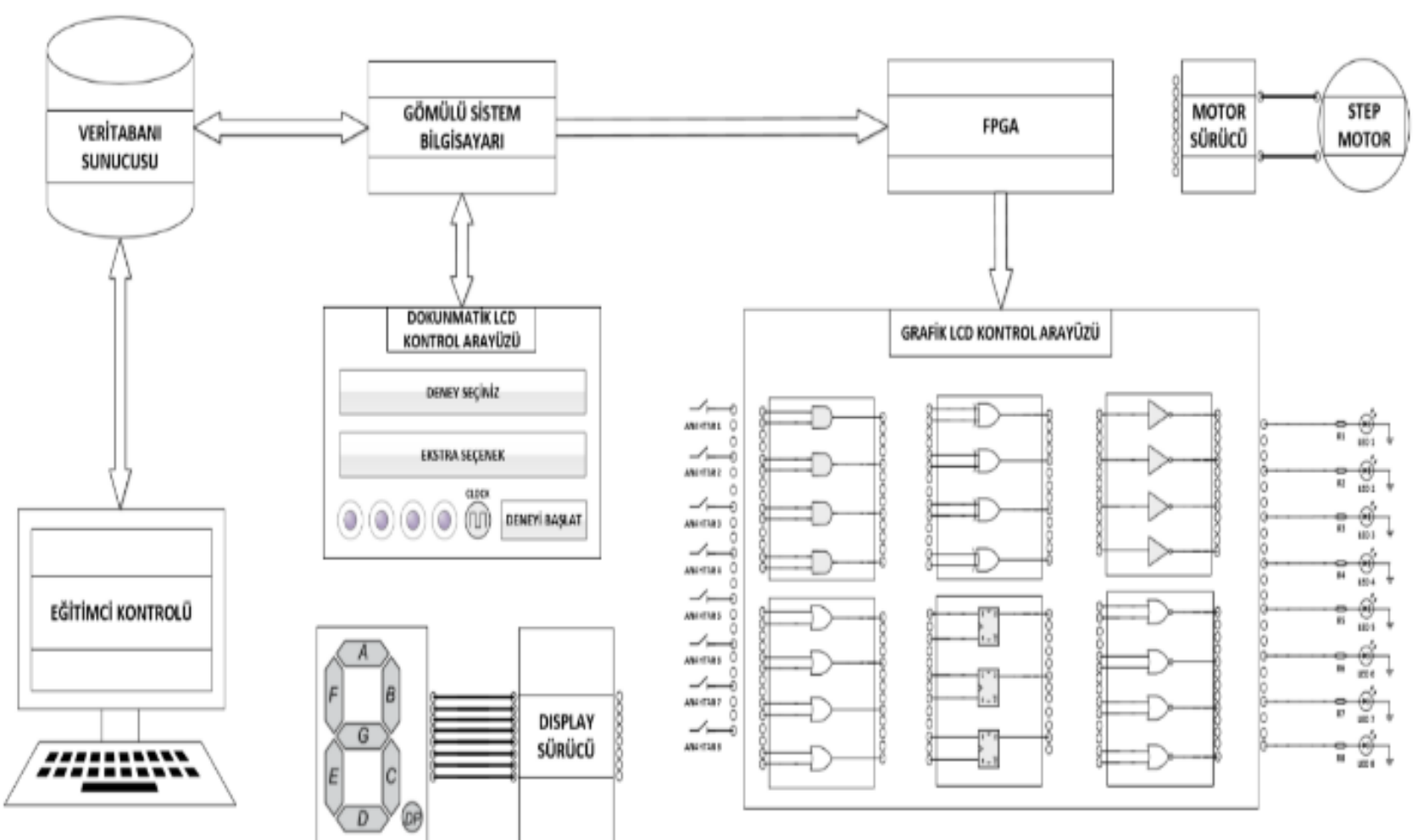

Şekil 2. Deney seti blok diyagramı

(Experiment set block diagram)

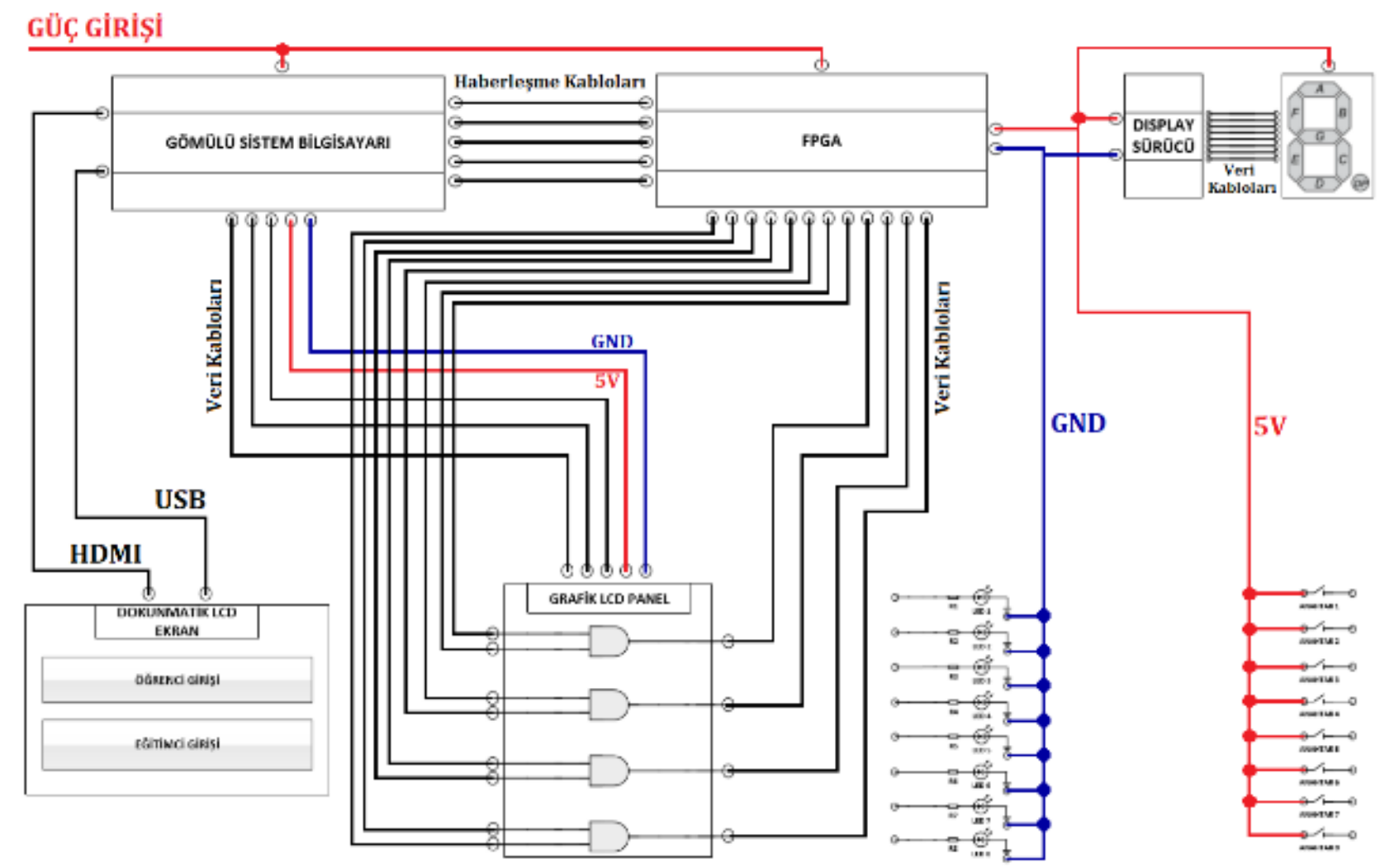

Şekil 3. Deney seti temsili elektronik bağlantıları (Experiment set representation electronic connections) 


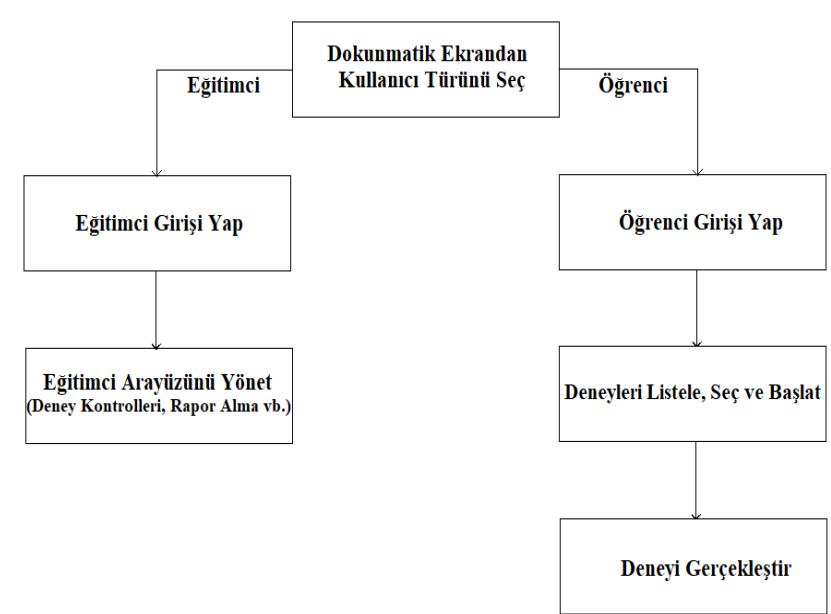

Şekil 4. Deney seti işlem akış diyagramı (Experiment set process flow diagram)

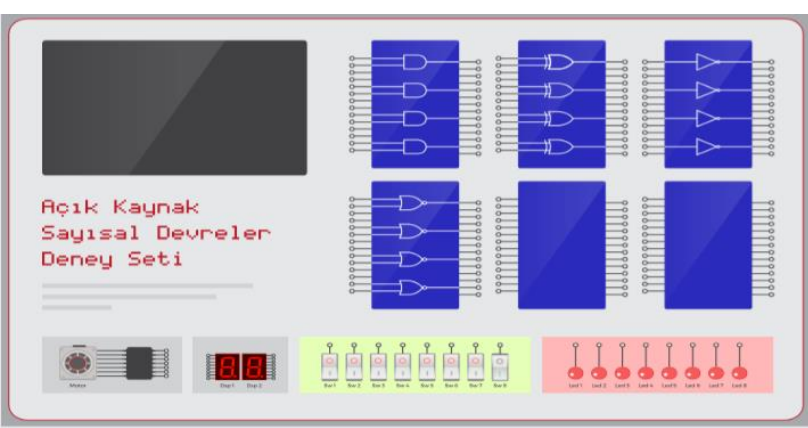

Şekil 5. Deney seti ön yüz tasarımı (Experiment set front face design)

BEGIN|

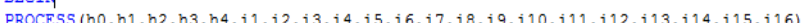

BEGIN

IF $h_{4}={ }^{\prime} 0^{\prime}$ and $h_{3}={ }^{\prime} 0^{\prime}$ and $h_{2}={ }^{\prime} 0^{\prime}$ and $h_{1}=0^{\prime}$ and $h_{0}={ }^{\prime}{ }^{\prime}$ ' THE

$01<=11$ and 12 ;

$02<=13$ and 14

$03<=15$ and 16 ;

$04<=17$ and 18 ;

ELSE

END IF;

END PROCESS;

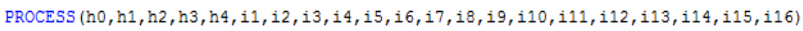
BEGIN

IF $h_{4}={ }^{\prime} 0^{\prime}$ and $h_{3}={ }^{\prime}{ }^{\prime}$ and $h_{2}={ }^{\prime} O^{\prime}$ and $h_{1}={ }^{\prime}{ }^{\prime}$ and $h_{0}=0^{\prime}$ THEN

$05<=19$ or 110 ;

$06<=111$ or 112

$07<=113$ or 114

$08<=115$ or 116

ELSE

END PROCESS

Şekil 6. Tasarımın örnek VHDL kod parçası (Example VHDL code part of the design)

\subsection{Arayüz Uygulamasının Geliştirilmesi (Interface} Application Development)

Arayüz uygulaması ile veritabanının birlikte çalışabilmesini sağlayabilmek amacıyla bir veritabanı bağlantı sınıfı oluşturulmuştur. Deney setinin başlatılmasıyla birlikte sete ait tüm bilgilerin tutulduğu veritabanı bilgileri deney setine aktarılmıştır. Deney setinde kullanıcıların gerçekleştirebilecekleri deneylerin devre elemanlarına ve deney uygulamalarına erișebilmeleri gömülü sistem bilgisayarına bağlı bir dokunmatik LCD panel aracılığıyla sağlanmaktadır. Arayüz uygulamasının dokunmatik LCD ekran üzerindeki anasayfa ekran görüntüsü Şekil 7'de verilmiştir.

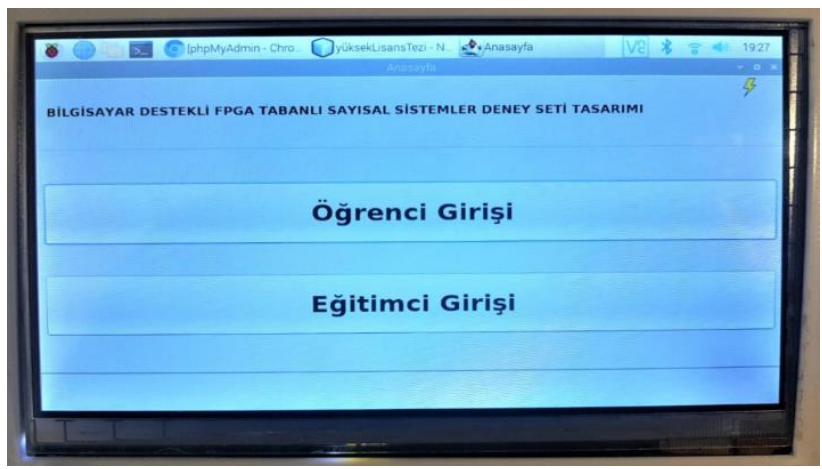

Şekil 7. Arayüz uygulamasının anasayfa görüntüsü (General view of the interface application)

Deney seti açıldığında dokunmatik LCD panel üzerinde ilk olarak öğrencilerin ve eğitimcilerin giriş seçeneklerini bulunduran bir ekran görüntülenmektedir. Kullanıcıların deney setini kullanabilmesi için öncelikli olarak bu ekrandan giriş türünü seçmesi ve ardından açılacak giriş ekranından giriş yapmaları gerekmektedir. Giriş işlemi hem öğrenciler hem de eğitimciler için veritabanına önceden kaydedilmiş olan kullanıcı adı ve parola bilgileri ile yapılmaktadır. Kullanıcı adı ve şifre ekranlarının görüntüleri Şekil 8'de verilmiştir.

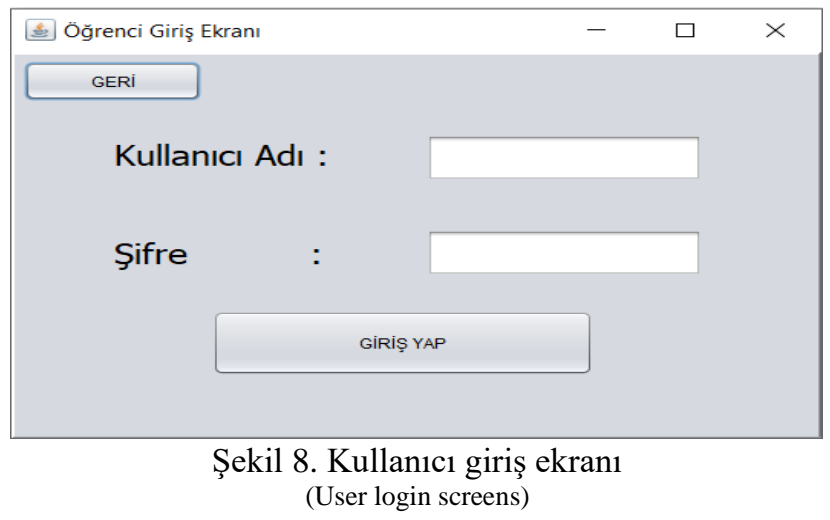

Öğrenciler giriş işlemini gerçekleştirdikten sonra karşılarına uygulamanın asıl işlevlerinin gerçekleştirildiği deney seçim ekranı gelmektedir. Bu ekran üzerinde "Deneyleri Listele" düğmesine basarak uygulayabilecekleri deneylerin isimlerini sol taraftaki liste bileşeninde görebilmektedirler. Uygulamak istedikleri deneyi seçerek "Deneyi Başlat" düğmesine basmaları ile seçilen deney verileri FPGA kartına aktarılmakta ve grafik LCD paneller üzerine ilgili deneyin devre elamanlarının görselleri bastırılmaktadır. Deneylerin listelendiği ve deney seçim işlemlerinin gerçekleştirildiği ekran Şekil 9'da verilmiştir.

"Deneyi Başlat" düğmesine basılmasıyla deney verileri giriş-çıkış pinleri vasıtasıyla FPGA kartına aktarılmaktadır. Bu işlem esnasında arayüz uygulamasında seçilen deney verisinin pinlere yönlendirilmesi işlemi Raspberry Pi için geliştirilmiş olan Pi4J Java kütüphanesi ile sağlanmıştır [19].

Öğrencilerin deneyleri başlatmasıyla birlikte, başlatılan deneylerin adı, başlatılma saati ve tarih bilgileri 
uygulamayı yapan öğrencinin bilgileriyle beraber veritabanına kaydedilmektedir. Eğitimcilerin öğrencileri uzaktan kontrol edebilmelerine olanak sağlayabilmek için deney verilerinin eklendiği veritabanı bir web sunucusu aracılığıyla canlı erişim ortamına aktarılmıştır. Bu veritabanı sunucusu yerel bilgisayarda yer almaktadır. Eğitimciler, geliştirilen uygulama üzerinden sisteme giriş yaptıktan sonra kendilerine sunulan özel arayüzü kullanarak hangi öğrencinin hangi deneyi yaptığını, deneylerin gerçekleştirildiği tarih ve saat bilgilerini ağ ortamında kolaylıkla kontrol edebilmektedir. Eğitimci kontrol ekranının görseli Şekil 10'da verilmiştir.

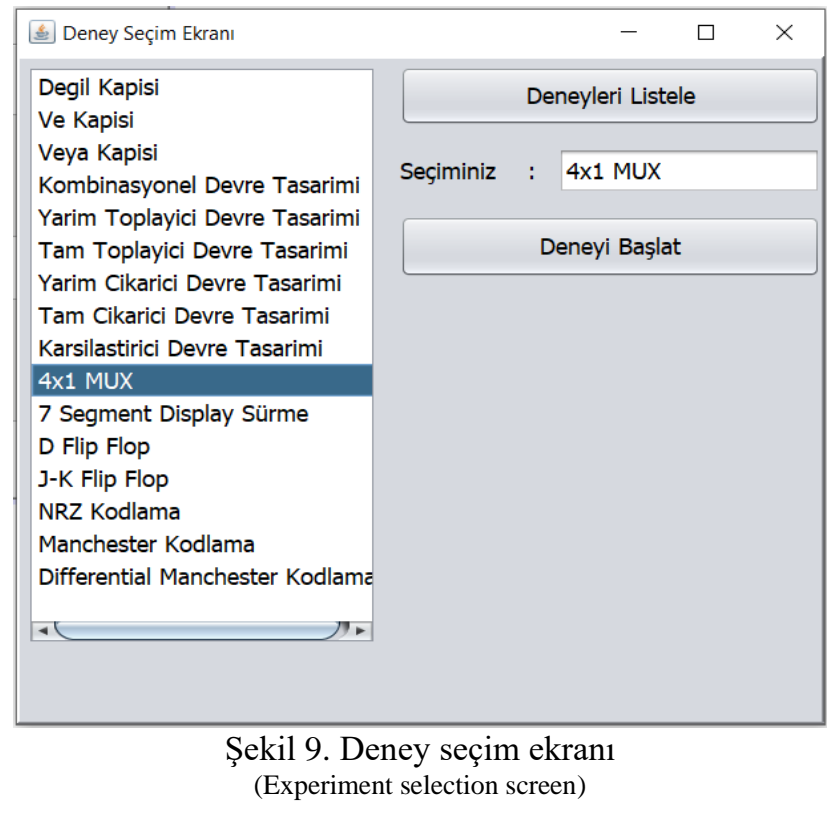

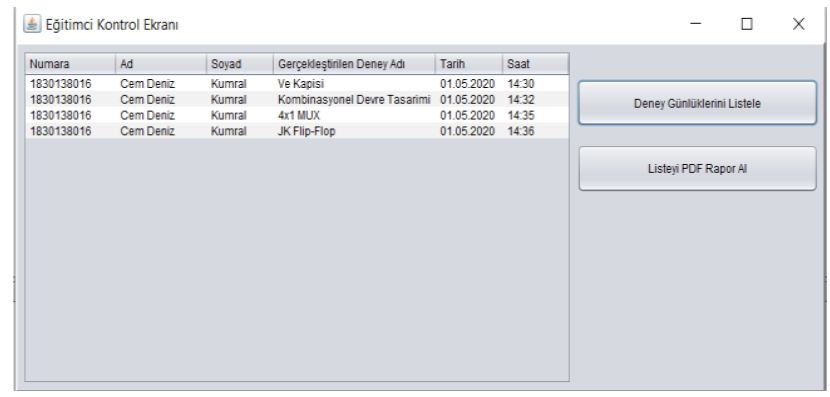

Şekil 10. Eğitimci kontrol ekranı

(Educator control screen)

\subsection{Deney Setinin Dlş Plaka Çizimi ve Baskı İşlemleri (External Plate Drawing and Printing Processes of the Experiment Set)}

Deney setinin tüm bileşenlerinin yerleştirileceği diş plakanın çizim işlemleri AutoDesk Fusion 360 ortamında gerçekleştirilmiştir. Üretilen deney setinin üst yüzeyinin ölçüleri 39x23cm şeklindedir. Ön kısmın yüksekliği $5 \mathrm{~cm}$ ve arka kısmın yüksekliği $8 \mathrm{~cm}$ olacak şekilde üç boyutlu bir prizma model tasarlanmıştır. Çizim işlemleri sonucunda oluşan dış plaka tasarımı Şekil 11'de verilmiştir.

Oluşturulan dış plaka tasarımının baskı işlemleri üç boyutlu yazıcı vasıtasıyla gerçekleştirilmiştir. Tasarımın dış yüzeyi için beyaz renkli filament tercih edilmiştir. Baskının yapıldığ tasarım üst, alt, yan, ön ve arka yüzeyler ayrı olacak şekilde parçalara ayrılmış ve bu şekilde baskı işlemi tamamlanmıştır. Baskı sonucunda elde edilen diş plaka parçaları Şekil 12'de verilmiştir.
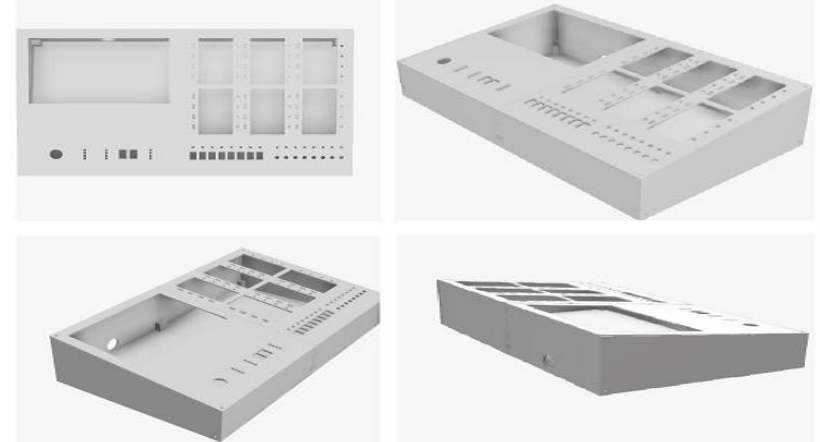

Şekil 11. Deney setinin dış plaka çizimi (Outer plate drawing of the experiment set)

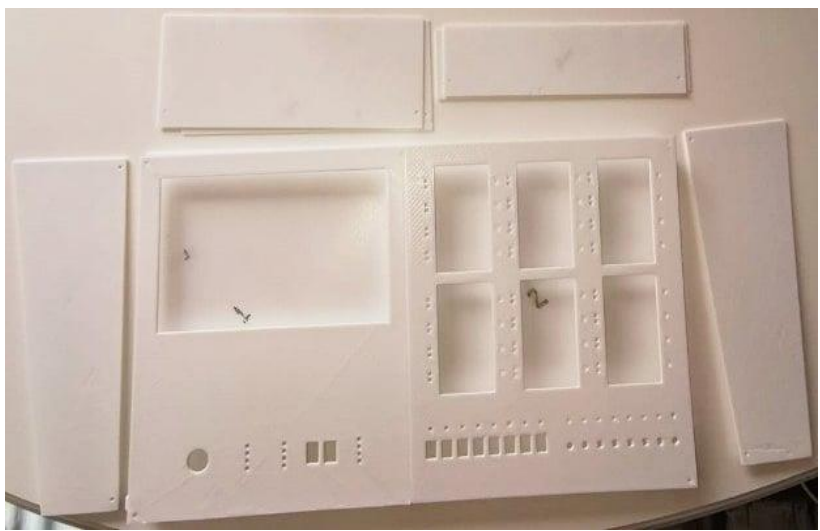

Şekil 12. Deney setinin baskı parçaları (Pressure pieces of the experiment set)

Çalışma sonucunda oluşturulan prototip tasarım yaklaşık $1.8 \mathrm{Kg}$ ağırlığındadır. Ortaya çıkan tasarımın iç kısmında boşluklar bulunmakta ve bu sebeple deney seti hem boyut olarak küçültülebilecek hem de ağırlığı azaltılabilecek durumdadır. Oluşturulan tasarımın tamamlanması Ar-Ge süreci nedeniyle yaklaşık 3 aylık bir zaman almıştır. Elde edilen son tasarımın tekrardan yapılma işlemi dış plakanın baskısı dahil ortalama 5 gün sürmektedir.

\section{ARAŞTIRMA BULGULARI (RESEARCH FINDINGS)}

Geliştirilen deney seti tasarımına 16 adet deney eklenmiştir. Bu senaryoların sıralaması en temel deneyden başlayarak daha karmaşık devre tasarımlarını içeren deneylere doğru ilerlemektedir. İsteğe bağlı olarak sabit deneyler dışında öğrenciler için serbest çalışma seçeneği sunulmakta ve burada deney setinde sunulan devre elemanları ile istenilen serbest deneyler gerçekleştirilebilmektedir. Eklenen deney senaryoları "Değil Kapısı", "Ve Kapısı", "Veya Kapısı", "Kombinasyonel Devre Tasarımı", "Yarım Toplayıcı Devre", "Tam Toplayıcı Devre", "Yarım Çıkarıcı Devre”, "Tam Çıkarıcı Devre”, "Tam Karşılaştırıcı Devre”, “4x1 
MUX Tasarımı”, “7 Segment Display Sürme”, “D Flip Flop", "J-K Flip Flop", "NRZ Kodlama", "Manchester Kodlama" ve "Differential Manchester Kodlama" şeklindedir. Deney seti üzerinde uygulanabilen bazı deney senaryoları ayrı başlıklar altında anlatılmıştır.

\subsection{VE Kapısı Deney Senaryosu (AND Gate Experiment Scenario)}

VE kapısı da lojik devre uygulamalarının en temel devre elemanlarından biridir. İki giriş ve bir çıkıştan meydana gelmektedir. Mantıksal olarak, verilen iki giriş değerinin çarpım sonucunun çıkışa verildiği şekilde bir işlem gerçekleştirmektedir.

Tasarlanan deney seti üzerinde VE kapısı deneyini gerçekleştirebilmek için giriş yaparak deney seçim ekranında "Ve Kapisi" deneyi seçilmelidir. Seçim işlemi gerçekleştikten sonra deney seti üzerinde bulunan grafik LCD panellerden birinde 4 adet VE kapısı devre elemanı otomatik olarak oluşmaktadır. VE kapısı deneyi uygulanırken çizimlerin yapıldığı grafik LCD panelin yanında bulunan portlardan, kullanılmak istenen VE kapısının giriş-çıkışlarına karşılık gelen portlar öğrenci tarafindan tespit edilmelidir. Daha sonra herhangi iki anahtar portu ile tespit edilen girişlerin portu arasında atlama kabloları yardımıyla bağlantı yapılmalıdır. Kullanılacak kapının çıkışına karşılık gelen port ile de LED'lerden herhangi birinin bağlı olduğu port arasında bağlantı yapılmalıdır. Bağlantı işlemleri tamamlandıktan sonra giriş portlarına bağlı anahtar çifti “ 00 ", " 01 ” ve "10" konumlarında iken çıkış portuna bağlı olan LED'in " 0 ", giriş portuna bağlı anahtar çifti " 11 " konumunda iken ise çıkış portuna bağlı olan LED'in "1" konumuna geçtiği gözlemlenmelidir. VE kapısı deneyinin deney seti üzerindeki uygulaması Şekil 13'te verilmiştir.

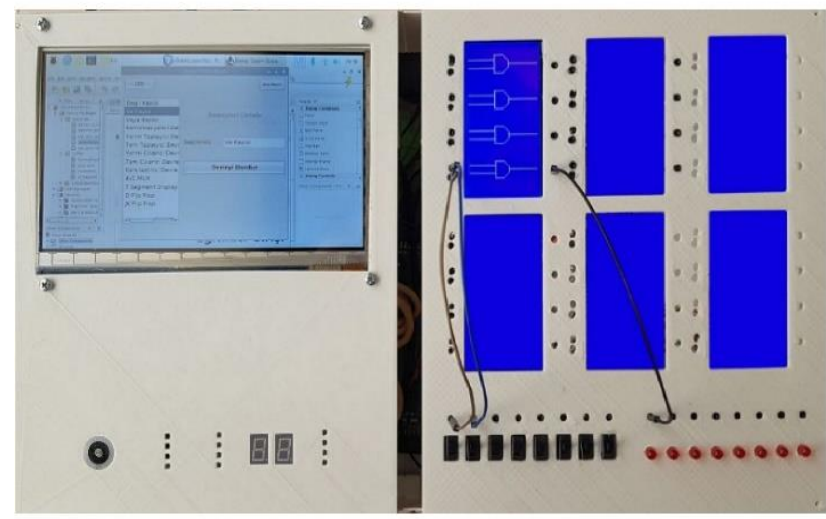

Şekil 13. VE kapısı deney seti uygulaması (AND gate experiment set application)

\subsection{Kombinasyonel Devre Tasarımı Deney Senaryosu (Combinational Circuit Design Experiment Scenario)}

Elektronik cihazların içerisinde bulunan devre elemanları genelde tek başlarına kullanılmazlar. Lojik devre elamanları, belirli bir işlevi yerine getirebilmek amacıyla bir araya getirilerek tümleşik bir devre yapısı oluşturulur.
Oluşan bu devre yapısına kombinasyonel lojik devre adı verilir. Öğrenciler Geliştirilen deney seti tasarımında "VE", "VEYA", ve "DEĞİL" kapıları kullanılarak istenilen kombinasyonel devre tasarımları oluşturulabilmektedir.

Tasarlanan deney seti üzerinde kombinasyonel devre deneyini gerçekleştirebilmek için giriş yaparak deney seçim ekranında "Kombinasyonel Devre Tasarimi” deneyi seçilmelidir. Seçim işlemi gerçekleştikten sonra deney seti üzerinde bulunan grafik LCD panellerden birinde 4 adet DEĞİL kapısı, birinde 4 adet VE kapısı ve birinde de 4 adet VEYA KAPISI devre elemanı otomatik olarak oluşmaktadır. Kombinasyonel devre deneyi uygulanırken çizimlerin yapıldığ 1 grafik LCD panellerin yanında bulunan portlardan, kullanılmak istenen DEĞİL, VE, VEYA kapılarının giriş-çıkışlarına karşılık gelen portlar öğrenci tarafından tespit edilmelidir. Daha sonra kullanılmak istenen anahtar portları ile tespit edilen girişlerin portları arasında bağlantı yapılmalıdır. Kombinasyonel bir devre tasarımı yapılması sebebiyle kullanılan kapıların çıkışlarına karşılık gelen portlar ile de devrenin devamında kombine edilen devre elemanının girişleri arasında bağlantı yapılmalıdır. Son olarak kombinasyonel devrenin nihai çıkışı ile kullanılmak istenen bir LED'in bağlı olduğu port arasındaki bağlantı yapılarak tasarım tamamlanmalıdır. Bağlantı işlemleri tamamlandıktan sonra deneyin doğruluk tablossundaki tüm kombinasyonlara göre giriş portlarına bağlı anahtarların konumları değiştirilerek çıkış portuna bağlı LED'in durumu gözlemlenmelidir. Kombinasyonel devre tasarımı deneyinin deney seti üzerindeki uygulaması Şekil 14'te verilmiştir.

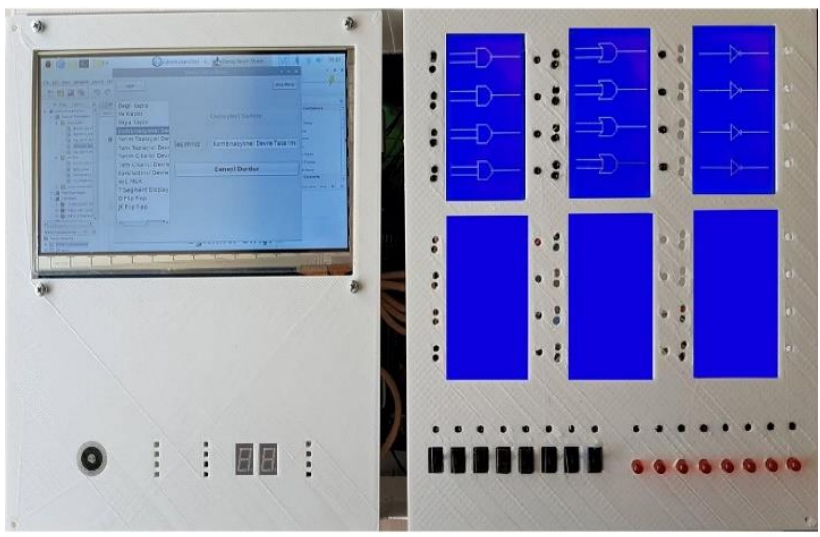

Şekil 14. Kombinasyonel devre deney seti uygulaması (Combinational circuit experiment set application)

\subsection{Tam Toplaylcı Devre Deneyi Senaryosu (Full Adder Circuit Experiment Scenario)}

Tam toplayıcı devreler ikilik tabanda toplama işlemini gerçekleştiren mantıksal devrelerdir. $\mathrm{Bu}$ devre tasarımlarında girişlere verilen ikili sistemle ifade edilen sayıları toplayıp çıkışa toplanmış şekilde aktarmayı sağlayan bir işlem yürütülmektedir. İkilik formatta üç adet bir bitlik sayının toplama işlemini gerçekleştirmektedir. Tam toplayıcı devreler iki adet yarım toplayıcı devrenin 
belirli bir lojik kombinasyonu ile meydana gelmektedir. Tam toplayıcı devresinde O ifadesi "toplam" çıkışını ve CO ifadesi de "elde" çıkışını temsil etmektedir. Cin (Carry in) ifadesi ise elde girişini temsil etmektedir. Bu giriş devrenin başka bir devre çıkışına bağlanması durumunda kullanılır ve bağlı olduğu devreden gelecek elde sonucunu da toplama işlemine dahil eder.

Tasarlanan deney seti üzerinde tam toplayıcı devre deneyini gerçekleştirebilmek için giriş yaparak deney seçim ekranında "Tam Toplayici Devre Tasarimi" deneyi seçilmelidir. Seçim işlemi gerçekleştikten sonra deney seti üzerinde bulunan grafik LCD panellerden birinde 4 adet VE kapıs1, birinde 4 adet VEYA kapıs1, birinde de 4 adet XOR kapısı devre elemanı otomatik olarak oluşmaktadır. Tam toplayıcı devre deneyi uygulanırken çizimlerin yapıldığg1 grafik LCD panellerin yanında bulunan portlardan, kullanilmak istenen VE, VEYA ve XOR kapılarının giriş-çıkışlarına karşılık gelen portlar öğrenci tarafindan tespit edilmelidir. Daha sonra kullanılmak istenen 3 adet anahtar portu ile tespit edilen girişlerin portları arasında bağlantı yapılmalıdır. Çıkışlar için kullanılmak istenen 2 adet LED portu ile de $\mathrm{O}$ çıkışı ve CO çıkışının portları arasında bağlantı yapılmalıdır. Bağlantı işlemleri tamamlandıktan sonra deneyin doğruluk tablosundaki tüm kombinasyonlara göre giriş portlarına bağlı anahtarların konumları değiştirilerek $\mathrm{O}$ ve $\mathrm{CO}$ çıkış portlarına bağlı LED'lerin durumu gözlemlenmelidir. Tam toplayıcı devre tasarımı deneyinin deney seti üzerindeki uygulaması Şekil 15 'te verilmiştir.

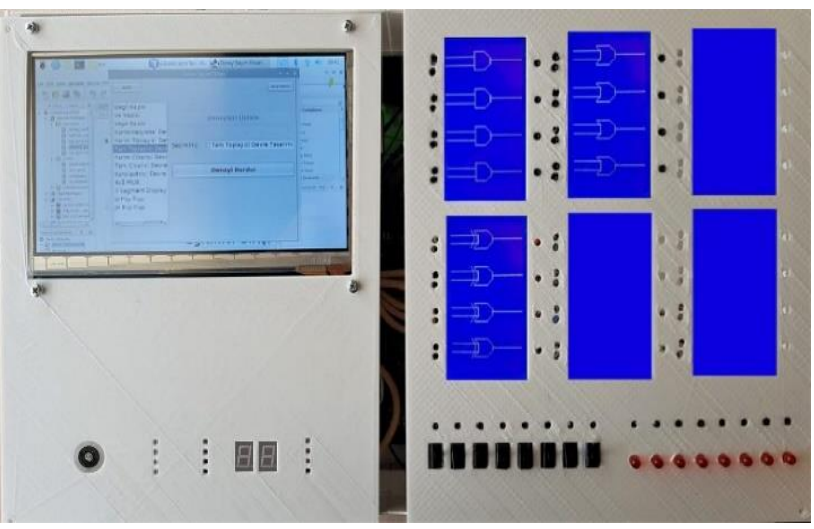

Şekil 15. Tam toplayıcı devre deney seti uygulaması (Full adder circuit experiment set application)

\subsection{Karşılaştırıcı Devre Deneyi Senaryosu (Comparator Circuit Experiment Scenario)}

Karşılaştırıcı devreler ikilik tabanda karşılaştırma işlemini gerçekleştiren mantıksal devrelerdir. $\mathrm{Bu}$ devre tasarımlarında girişlere verilen ikili sistemle ifade edilen sayıların karşılaştırmasını gerçekleştirip işlem sonucunu çıkışa aktarmayı sağlayan bir işlem yürütülmektedir.

Tasarlanan deney seti üzerinde karşılaştırıcı devre deneyini gerçekleştirebilmek için giriş yaparak deney seçim ekranında "Karsilastirici Devre Tasarimi" deneyi seçilmelidir. Seçim işlemi gerçekleştikten sonra deney seti üzerinde bulunan grafik LCD panellerden birinde 4 adet
VE kapısı, birinde 4 adet DEĞİL kapısı, birinde de 4 adet XOR kapısı devre elemanı otomatik olarak oluşmaktadır. Karşılaştırıcı devre deneyi uygulanırken çizimlerin yapıldığ kullanılmak istenen VE, DEĞIL ve XOR kapılarının girişçıkışlarına karşılık gelen portlar öğrenci tarafından tespit edilmelidir. Daha sonra kullanılmak istenen 2 adet anahtar portu ile tespit edilen girişlerin portları arasında bağlantı yapılmalıdır. Çıkışlar için kullanılmak istenen 3 adet LED portu ile de "I0 < I1", "I0 = I1" ve "I0 > I1" çıkışlarının portları arasında bağlantı yapılmalıdır. Bağlantı işlemleri tamamlandıktan sonra deneyin doğruluk tablosundaki tüm kombinasyonlara göre giriş portlarına bağlı anahtarların konumları değiştirilerek "I0 < I1", "I0 = I1" ve "I0 > I1" çıkış portlarına bağlı LED’lerin durumu gözlemlenmelidir. Karşılaştırıcı devre tasarımı deneyinin deney seti üzerindeki uygulaması Şekil 16'da verilmiştir.

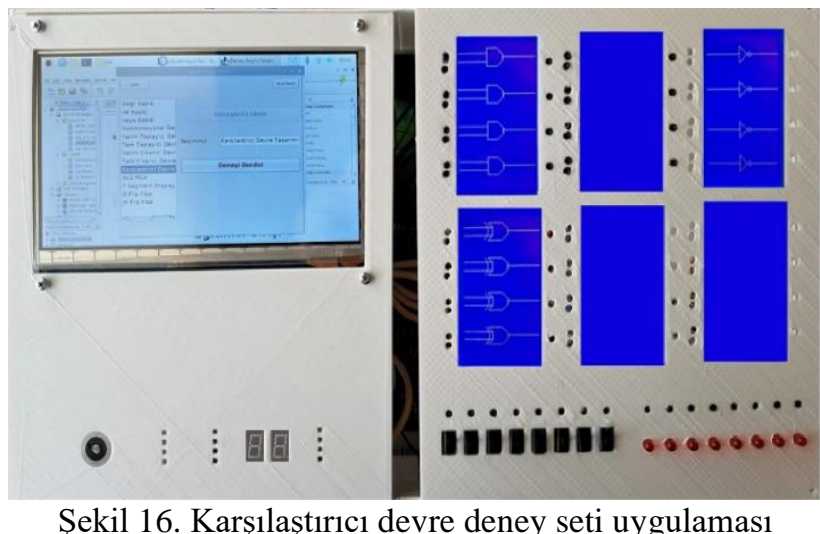

Şekil 16. Karşılaştırıcı devre deney seti uygulaması (Comparator circuit experiment set application)

\subsection{4xl MUX (Çoklayıcl) Deneyi Senaryosu (4xl MUX (Multiplexer) Experiment Scenario)}

Birden fazla giriş hattından gelen bilgilerden birisini seçerek uygun çıkış hattına yönlendirilmesini sağlayan kombinasyonel devrelere MUX (Multiplexer, Çoklayıcı) denir. Çok sayıda veri transferi, zaman paylaşım tekniği kullanılarak çoklayıcı devreleri yardımıyla gerçekleştirilmektedir.

Tasarlanan deney seti üzerinde $4 \times 1$ MUX deneyini gerçekleştirebilmek için giriş yaparak deney seçim ekranında " $4 x 1$ MUX" deneyi seçilmelidir. Seçim işlemi gerçekleştikten sonra deney seti üzerinde bulunan grafik LCD panellerden birinde 1 adet 4x1 MUX devre elemanı otomatik olarak oluşmaktadır. 4x1 MUX devresi deneyi uygulanırken çizimlerin yapıldığı grafik LCD panellerin yanında bulunan portlardan seçiciler, girişler ve çıkışa karşılık gelen portlar öğrenci tarafından tespit edilmelidir. Daha sonra kullanılmak istenen 6 adet anahtar portu ile tespit edilen seçicilerin ve girişlerin portları arasında bağlantı yapılmalıdır. Çıkış için kullanılmak istenen LED portu ile de $\mathrm{O}$ çıkışının portu arasında bağlantı yapılmalıdır. Bağlantı işlemleri tamamlandıktan sonra deneyin doğruluk tablosundaki tüm kombinasyonlara göre seçiciler ve girişlerin portlarına bağlı anahtarların konumları değiştirilerek $\mathrm{O}$ çıkış portuna bağlı LED'in 
durumu gözlemlenmelidir. 4x1 MUX deneyinin deney seti üzerindeki uygulaması Şekil 17'de verilmiştir.

\subsection{Flip-Flop Deneyi Senaryosu (D Flip-Flop Experiment Scenario)}

D (Data) tipi flip-flop, bilgi kaydetmede kullanılan bir flipflop devresidir ve genellikle kaydedici devrelerinde kullanılmaktadır. Tasarlanan deney seti üzerinde D flipflop deneyini gerçekleştirebilmek için giriş yaparak deney seçim ekranında "D Flip-Flop" deneyi seçilmelidir. Seçim işlemi gerçekleştikten sonra deney seti üzerinde bulunan grafik LCD panellerden birinde 3 adet D flip-flop devre elemanı otomatik olarak oluşmaktadır. D flip-flop deneyi uygulanırken çizimlerin yapıldığı grafik LCD panelin yanında bulunan portlardan, kullanılmak istenen D flipflop'un giriş-çıkışlarına karşılık gelen portlar öğrenci tarafından tespit edilmelidir. Daha sonra herhangi bir anahtar portu ile tespit edilen giriş portu arasında atlama kablosu yardımıyla bağlantı yapılmalıdır. Kullanılacak D flip-flop'un çıkışına karşılık gelen port ile de LED'lerden herhangi birinin bağlı olduğu port arasında bağlantı yapılmalıdır. Clock sinyali otomatik olarak ayarlanmış durumda ve deneyin başlatılması ile aktif olmaktadır. Bağlantı işlemleri tamamlandıktan sonra doğruluk tablosundaki tüm kombinasyonlara göre giriş portuna bağlı anahtarın konumu değiştirilerek çıkış portuna bağlı olan LED'in durumu gözlemlenmelidir. D flip-flop deneyinin deney seti üzerindeki uygulaması Şekil 18'de verilmiştir.

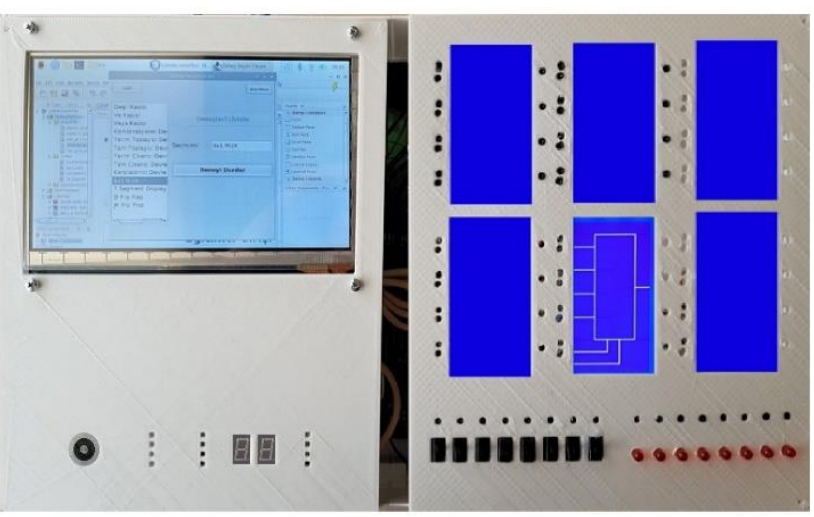

Şekil 17. 4x1 MUX deney seti uygulaması (4x1 MUX experiment set application)

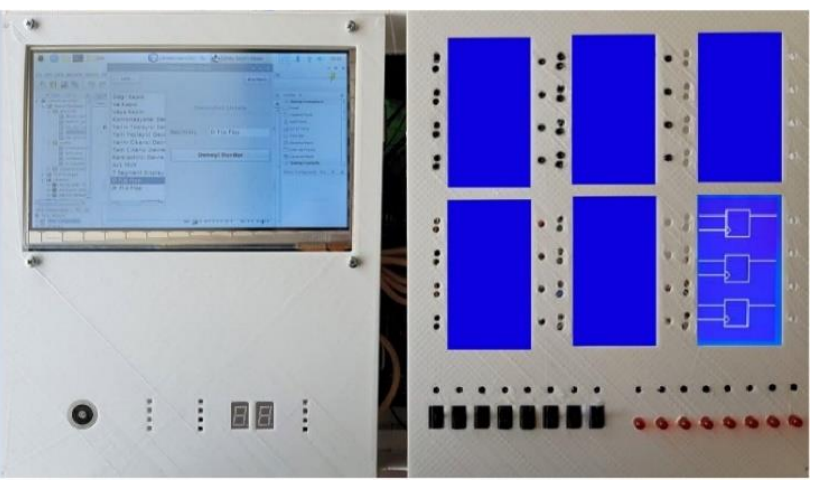

Şekil 18. D flip-flop deney seti uygulaması (D flip-flop experiment set application)

\section{DENEY SETINIIN PERFORMANSI VE KAYNAK KULLANIM ANALIZİ (PERFORMANCE AND RESOURCE UTILIZATION ANALYSIS OF EXPERIMENT SET)}

Geliştirilen deney setinin arayüz uygulaması Raspberry Pi gömülü sistem bilgisayarı üzerinde geliştirilmiştir. Raspberry Pi üzerinde arayüz uygulaması ve veritabanı işlemleri etkin ve kararlı bir biçimde çalışmaktadır. Kullanılan gömülü sistem bilgisayarı 1 GB RAM kapasitesine sahip olmasına rağmen uygulamanın çalışma zamanında herhangi bir yavaşlama veya problem ile karşılaşılmamıştır. Gömülü sistemin dokunmatik LCD ekran ile doğrudan bağlantı sağlayabilmesi büyük bir avantaj sağlamıştır.

Deney setinin içeriğinde bulunan deneylerin mantıksal işlemlerinin gerçekleştirilmesi Xilinx Spartan XC3S500E FPGA kartı ile sağlanmıştır. Seçilen deneyler uygulanırken giriş-çıkış verilerinin işlenmesi sırasında herhangi bir problem gözlemlenmemiştir. İşlemler nanosaniyeler mertebesinde hızlı ve kararlı bir şekilde gerçekleşmektedir. Kartta bulunan giriş-çıkış pin sayısı deney seti gereksinimlerini rahat bir şekilde karşılamıştır. Geliştirilen deney seti için oluşturulan FPGA tasarımının kullanılan kart üzerindeki kaynak kullanım oranları Tablo 3'te verilmiştir.

Tablo 3. FPGA işlemcisinin kaynak kullanım analizi (Source utilization rates of the FPGA processor)

\begin{tabular}{|c|c|c|c|}
\hline Birim & Kullanılan & Toplam & $\begin{array}{c}\text { Kullanım } \\
\text { Oranı }\end{array}$ \\
\hline Slice & 50 & 4656 & $\% 1$ \\
\hline Slice Flip-Flop & 6 & 9312 & $\% 0,07$ \\
\hline LUT & 100 & 9312 & $\% 1$ \\
\hline Giriş-Çıkış Pini & 76 & 116 & $\% 66$ \\
\hline Clock Sinyal Pini & 1 & 24 & $\% 4$ \\
\hline
\end{tabular}

Geliştirilen deney seti kapsamında FPGA kaynak kullanımları bakımından oldukça tatmin edici değerler gözlemlenmiştir. Sistem, çalışma esnasında FPGA üzerinde bir yük oluşturmadığından 1sınma, gecikme gibi sorunlar ile karşılaşılmamıştır. Her deney için uygulama testleri gerçekleştirilmiş ve deneylerin doğruluk tablolarındaki değerler ile uyumlu sonuçlar alınmıştır. FPGA kartında bulunan mantıksal kaynakların \%1'lik bir kısmı kullanılmış olsa da gelecek çalışmalarda deney setinin çok fazla sayıda ders ve konunun deneylerini içereceği durumlarda aygıtın mantıksal kaynaklarına ve performansına büyük oranda ihtiyaç duyulacaktır. Bu sebeple bu özelliklere sahip bir cihaz kullanımı tercih edilmiştir.

Deney setindeki en önemli işlemlerden biri gömülü sistem ile FPGA platformunun haberleşmesidir. İki bileşen arasındaki haberleşme her iki kart üzerinde de bulunan giriș-çıkıș pinleri aracılığıyla sağlanmıștır. Giriş-çıkış pinleri kare dalga şeklinde lojik sinyaller ile çalışmaktadır. Gömülü sistem haberleşme pinlerinden çıkan kare dalgaların gecikme ve veri kaybı yaşamadan FPGA kartına aktarıldığ 1 , başlat düğmesine basıldığı anda deneylerin hızlıca başladığı gözlenmiştir. 
Öğrencilerin deneyleri başlatmasıyla birlikte deneyin adı, başlatılma saati ve tarih bilgileri, uygulamayı gerçekleştiren öğrencinin numara, ad ve soyad bilgileri veritabanına kaydedilmektedir. Eğitimcilerin öğrencileri uzaktan kontrol edebilmelerine olanak sağlayabilen özel bir panel geliştirilmiştir. Eğitimcilerin, sisteme giriş yaptıktan sonra kendilerine sunulan arayüz ile gerçekleştirilen deneyleri kolaylıkla kontrol edebilmeleri sağlanmıştır. Geliştirilen deney setinin özellikleri bakımından literatürde bulunan bazı çalışmalar ile karşılaştırması Tablo 4'te verilmiştir.

Tablo 4. Deney setinin literatürdeki çalışmalar ile karşıllaştırılması

(Comparison of the experiment set with the studies in the literature)

\begin{tabular}{|c|c|c|c|c|}
\hline \multicolumn{6}{|c|}{ Çalışma Adı } & $\begin{array}{c}\text { İnternet } \\
\text { Erişimi }\end{array}$ & $\begin{array}{c}\text { Uzaktan } \\
\text { Kontrol }\end{array}$ & $\begin{array}{c}\text { Arayüz } \\
\text { Desteği }\end{array}$ & $\begin{array}{c}\text { Grafik } \\
\text { Desteği }\end{array}$ \\
\hline Yavuzçelik [8] & Var & Yok & Var & Yok \\
\hline Günaydın [9] & Var & Var & Var & Yok \\
\hline Arıcı [16] & Yok & Yok & Var & Var \\
\hline Köksal [12] & Yok & Yok & Var & Var \\
\hline Sarı [13] & Var & Var & Yok & Yok \\
\hline $\begin{array}{c}\text { Şimşek ve Taşdelen } \\
{[20]}\end{array}$ & Var & Var & Yok & Yok \\
\hline $\begin{array}{c}\text { Irmak ve Calpbinici } \\
\text { [21] }\end{array}$ & Var & Yok & Var & Yok \\
\hline Kaçar vd. [22] & Var & Var & Var & Yok \\
\hline Çakır ve Çıtak [23] & Yok & Yok & Var & Var \\
\hline Özdemirci vd. [24] & Yok & Yok & Yok & Yok \\
\hline $\begin{array}{c}\text { Geliştirilen Deney } \\
\text { Seti Tasarımı }\end{array}$ & Var & Var & Var & Var \\
\hline
\end{tabular}

Literatürde bulunan ve tabloda karşılaştırması yapılan çalışmalarda oluşturulan deney seti tasarımlarının maliyet, boyut ve ağırlık bilgisi net olarak verilmemiştir. Ayrıca bu çalışmalarda ortaya çıkarılan tasarımların hemen hemen hepsi ayrı çevre birimler halinde bulunan masaüstü prototip veya bilgisayar uygulaması şeklinde olup tek bir set üzerinde toplanmamıştır. Piyasada bulunan ticari ürünlere bakıldığında ise taşınabilir boyutta olanların grafik desteğinin olmadığı veya yetersiz olduğu görülmektedir. Bazı deney seti tasarımlarının da masaüstü veya dizüstü bir bilgisayara bağımlı olarak çalıştığı gözlemlenmiştir.

\section{TARTIŞMA VE SONUÇLAR (DISCUSSION AND RESULTS)}

Günümüzde farklı amaçlar için geliştirilmiş deney seti tasarımları bulunmaktadır. Bu deney setleri ticari veya akademik ortamlarda tasarlanarak geliştirme çalışmaları yapılmaktadır. Ancak mevcut deney setleri genellikle tek bir ders veya konu üzerinde uygulamalar yapılacak şekilde tasarlanmaktadir. Mevcut deney setlerinde yapılan devre tasarımları, sabit bir devre şeklinde tasarlanmış veya kullanılan programlanabilir cihazlar tek bir amacı yerine getirecek şekilde tasarlanmıştır. $\mathrm{Bu}$ sebeple oluşturulan devre tasarımlarına fiziki bir müdahale gerçekleştirmeden sistemin yapısını değiştirmek mümkün olmamaktadır. Ayrıca deney seti tasarımları elektronik ve mantıksal işlemlerin gerçekleştirilebildiği şekilde tasarlanmış olup kullanıcı ile arayüz etkileşimine yeterli önem verilmemiştir.

Geliştirilen deney seti tasarımında farklı dersler ve konuları içeren deney uygulamalarının tek bir deney seti üzerinde toplanması sağlanmıştır. Deney içeriklerinde bulunan devre elemanları veya tümleşik devre tasarımları VHDL aracılığıyla FPGA üzerinde oluşturulmuştur. FPGA'lar üretim aşamasından sonra tasarımcının yürütmek istediği işlemler doğrultusunda donanım yapısının değişmesine olanak sağlamaktadır. Bu özellik sayesinde, tasarlanan deney setine günümüz teknolojilerine uygun ve farklı devre tasarımlarını içeren deneylerin eklenmesi sağlanmıştır. Setin içeriğindeki deney senaryoları ve FPGA üzerinde oluşturulan devre tasarımları genişletilerek daha fazla alana hitap eden deney setleri oluşturulabilir.

Deney setinin içeriğinde bulunan arayüz uygulaması ve veritabanı işlemlerinin tümü Raspbery Pi gömülü sistem bilgisayarında geliştirilmiştir. Bu geliştirmeler için benzer mimaride işlem gerçekleştiren daha yüksek performansa sahip bir gömülü sistem bilgisayarları kullanılabilir. Kullanıcıların seçmiş olduğu deneylerde görev alan devre elemanlarının grafik LCD panellerde görüntülenmesi deneylere etkinlik ve hız kazandırmıştır. Birçok kurumda, derslerde gerçekleştirilen deneylerin kontrolü eğitimciler tarafından tek tek yapılmaktadır. Oluşturulan deney seti tasarımı sayesinde eğitimcilerin diledikleri zaman öğrencilerin yaptığı deneyleri daha hızlı ve kolay bir şekilde uzaktan kontrol edebilmeleri sağlanmıştır.

Önerilen deney setinin prototip tasarımı yaklaşık olarak 1500TL' ye mal edilmiştir. Yurtiçi ve yurtdışındaki benzer ürünler ile karşılaştırıldığında bu alanda çalışan firmaların ürettiği deney setlerinin $3000 \mathrm{TL}$ civarındaki fiyatlarda satışı söz konusudur.

Gerçekleştirilen çalışma sonucunda, FPGA mimarisinin esnek deney seti tasarımları gerçekleştirebilmek için uygun bir seçenek olduğu görülmüştür. Eğitim kurumlarının laboratuvar malzemeleri için ayırmış oldukları mali kaynakları azaltacak bir tasarım oluşturulmuştur. Eğitimlerde gerçekleştirilecek olan deneylerin hazırlık süreçleri kısaltılmış, deneylerin başarımının deney seti üzerinden takip edilebilmesi sağlanmış ve eğitim alan öğrencilerin eğitimden etkin bir biçimde fayda sağlaması imkânı elde edilmiştir. Bu özellikler sayesinde ergonomik, taşınabilir, kullanıcı dostu, eğitmenin öğrenciyi a ̆ ortamından uzaktan takip edebileceği tümleşik bir deney seti tasarımı oluşturulmuştur.

Gelecek çalışmalarda, deney setleri kullanılarak yapılan uygulamalı derslerin uzaktan eğitim yönetimi ile yürütülmesi durumunda internet üzerinden kontrol yapılabilmesini sağlayan modüllerin geliştirilmesi gerekmektedir. Bu sebeple veritabanı sunucusunun uzak bilgisayara geçirilmesi hedeflenmektedir. Geliştirilecek modüllerde, öğrencilerin uygulamalarda gerçekleştirdiği tüm işlemler kayıt altına alınarak uygulamalı uzaktan eğitim alanında ilerlemeler kaydedilebilir. 


\section{KAYNAKLAR (REFERENCES)}

[1] I. Colak, E. Irmak, E. Kabalci, F. Issi, "Design and implementation of a remote laboratory platform using Matlab Builder for NE", Computer Application in Engin. Education, 22 (4), 617-629, 2014.

[2] C. Kubat, A. Kiraz, "The modeling of tensile test in virtua laboratory design using artificial intelligence", Journal of the Faculty of Engineering and Architecture of Gazi University, 27 (1), 205-209, 2012

[3] J.A. Suul, D. Salvatore, G. Giuseppe, "Virtual synchronous machine-based control of a single-phase bi-directional battery charger for providing vehicle-togrid services", IEEE Transactions on Industry Applications, 52 (4), 3234-3244, 2016.

[4] Ç. Elmas, O. Özkaraca, "Güç Elektroniği Dersi için Hazırlanmış İnternet Üzerinden Eğitim Uygulaması”, Bilişim Teknolojileri Dergisi, 1 (2), 11-14, 2010.

[5] Internet: Sciencetech Inc., http://www.sciencetech-inc.com 13.05.2020.

[6] Internet: Yıldırım Elektronik, http://www.yildirimelektronik.com, 13.05.2020.

[7] B. Kobak, Bir Temel Deney Setinin Tasarımı ve İmali, Yüksek Lisans Tezi, Sakarya Üniversitesi, Fen Bilimleri Enstitüsü, 2006.

[8] N. B. Yavuzçelik, Web Tabanlı Elektronik Deney Seti Uygulaması, Yüksek Lisans Tezi, Marmara Üniversitesi, Fen Bilimleri Enstitüsü, 2008.

[9] R. Günaydın, Uzaktan Erişimli Web Tabanlı Mikrodenetleyici Deney Seti Tasarımı ve Gerçekleştirilmesi, Yüksek Lisans Tezi, Karabük Üniversitesi, Fen Bilimleri Enstitüsü, 2014.

[10] M. Özbek, Temel Haberleşme Laboratuvarı İçin Bilgisayar Destekli Modülasyon Demodülasyon Deney Seti, Yüksek Lisans Tezi, Gazi Üniversitesi, Fen Bilimleri Enstitüsü, 2014.

[11] P. Musik, "Development of Computer-Based Experiment Set on Simple Harmonic Motion of Mass on Springs", Turkish Online Journal of Educational Technology-TOJET, 16(4), 1-11, 2017.
[12] R. Köksal, H. Öztekin, F. Temurtaş, "Eğitim Amaçlı Mikrobilgisayar Sistemleri İçin I2C Seri Haberleşme Protokolü ile Analog Arayüz Tasarımı”, Elektrik, Elektronik, Bilgisayar ve Biyomedikal Mühendisliği Sempozyumu, 789-793, 2014.

[13] Y. Sarı, "Elektronik ve Otomasyon Laboratuvarında Pratik Eğitim Amaciyla PLC Kontrollü Bir Sistem Uygulaması", Firat Üniversitesi Mühendislik Bilimleri Dergisi, 28(1), 65-71, 2016.

[14] S. Karthik, N. Srividya, L. Swetha, J. Shilpa, "Improving Testability of Design in FPGA using Raspberry Pi”, Indian Journal of Science and Technology, 9(1), 1-4, 2016.

[15] İ. Işık, M.E. Tağluk, "FPGA Tabanlı Dijital Haberleşme Sistemlerinin System Generator Aracı ile Analizi”, Selçuk Üniversitesi Mühendislik, Bilim ve Teknoloji Dergisi, 6(2), 255265, 2018.

[16] İ. Arıc1, M. Tenruh, "Labview Tabanlı Bir Elektronik Deney Seti Geliştirilmesi”, Akademik Bilișim Konf., Mersin, 323-329, 2014.

[17] Internet: Waveshare Elektronik, https//www.waveshare.com/Open3S500E, 10.05.2020.

[18] Internet: Spartan-3E FPGA Family Data Sheet, https://www.xilinx.com/support/documentation/data_sheets/ds312 .pdf, 17.05.2020.

[19] Internet: Pi4J, https://pi4j.com/1.2/index.html, 20.05.2020.

[20] Şimşek, M. A., Taşdelen, K., “Arduino ile Tasarlanmış Sistemlerin İnternet Tabanlı Kontrolü ve İzlenmesi”, Uluslararası Teknolojik Bilimler Dergisi, 8(1), 20-33, 2019.

[21] E. Irmak, A. Calpbinici, "E-laboratuvarlar İçin Yeni Bir Tasarım: Eş Zamanlı Erişilebilen Deneysel Uygulama Platformu”, Journal of the Faculty of Engineering and Architecture of Gazi University, 32(2), 363-375, 2017.

[22] S. Kaçar, A. F. Boz, B. Arıcıoğlu, H. Tekin, "PID Denetleyici Uygulamaları İçin Yeni Bir Online Deney Seti Tasarımı”, Sakarya University Journal of Science, 21(1), 34-46, 2017.

[23] A. Çakir, Ü. Çitak, "Simulation of Logic Circuit Tests on Android Based Mobile Devices", Logical Methods in Computer Science, arXiv preprint arXiv:1805.12473, 2018

[24] E. Özdemirci, Ç. Ersin, M. R. Canal, "Arduino Uno Uygulama Setinin Gerçekleştirilmesi”, Mehmet Akif Ersoy Üniversitesi Fen Bilimleri Enstitüsü Dergisi, 8(1), 127-133. 2019. 